\title{
Necessity of education and awareness in farmers: the basis of agricultural progress in developing and underdeveloped nations
}

\author{
Poornima Sharma \\ Mata Gujri Women's College, Jabalpur- 482002, M.P, India \\ poornima.sharma@rediffmail.com
}

\begin{abstract}
Farmers with weak economic and educational background are mostly ignorant of the modern advances in the field of agricultural research. The outcome of a survey performed in selected rural areas of India implicates the extent of agricultural progress in these areas. Keeping in consideration the survey (agricultural field survey, diseased plant sampling, soil analysis and interview of farmers) a lecture session was organized for underprivileged farmers. A report of this work was communicated to the High Court of Madhya Pradesh, India and agriculture ministry of India in the form of a Public Interest Litigation (legal procedures incomplete).
\end{abstract}

Keywords: Rural development, modern agricultural technology, education

\section{INTRODUCTION}

Agriculture is the primary occupation of the larger part of Indian population. 65-70\% of Indian population is dependent on agriculture for their living. Rural population is in majority here and accounts for about $12 \%$ of world population (Misra, 2009). Madhya Pradesh; one of the Indian states, gives a considerable contribution to the agricultural economy of India. The state is rich in natural resources but suffer hindrance in progress due to educational and economic incompetence. Tribal regions are a prominent feature of this state with rich cultural heritage. Agriculture is the age old occupation of the natives of Madhya Pradesh. Agriculture is mostly rain fed. Traditional methods dominate over modern technologies as a large section of farmers here have low investment capacity.

The outcome of a survey performed in this region was communicated to the government authorities. A report based on this survey is being presented here. The report is divided into four sections.

- Field survey and sampling (diseased plants and soil)

- Interview of farmers

- Lecture delivered to farmers

- Communication with authorities to convey problems and demands of farmers

Field survey and sampling

Diseased plants sampling: Among all the other crops, pea is an important legume crop grown in this region. Madhya Pradesh is one of the largest producers of pea in India with productivity of about 48 $\mathrm{kg} / \mathrm{hac}$ (Tiwari et al., 2007).

A survey of pea plantation was carried out in three villages of Madhya Pradesh, namely, Ghana, Tilgava and Tilhari. In these regions, considerable number of plants showed yellowing, wilting and root rot disease. Selected fields of Ghana and Tilhari villages showed the symptoms in more than $40 \%$ of the field area, whereas, Tilgava showed symptoms in less than $10 \%$ of the field area.

Samples collected from the surveyed fields and also samples provided by farmers of other villages were subjected to laboratory analysis. All the diseased plant samples showed prominent yellowing and wilting in the lower parts of plant with symptoms extending further upwards. Roots showed red- brown lesions. Most of the plants studied were 30 to 50 days old. Seedlings were also studied which showed similar symptoms along with root rot. Vertical section of the roots showed red- brown streaks running upwards along the vascular tissue in many of the samples studied. The potential causal organisms were isolated from selected samples and subjected to pathogenicity test (Hwang et al. , 1995; Ondrej et al.; 2008). The pathogens thus isolated are mentioned in table 1 . The diagnosis was indicative of Fusarium near wilt and Fusarium wilt. 
Table 1: Most frequently isolated pathogens from roots of diseased pea plant samples.

\begin{tabular}{|l|l|}
\hline $\begin{array}{l}\text { Agricultural field location/ } \\
\text { Village }\end{array}$ & $\begin{array}{l}\text { Most frequently isolated } \\
\text { pathogen }\end{array}$ \\
\hline Ghana & Fusarium oxysporum \\
Amkhera & Fusarium oxysporum \\
Patan & Fusarium oxysporum \\
Shahpura & Fusarium oxysporum \\
Tilgava & Pythium sp. \\
Tilhari & Fusarium solani \\
\hline
\end{tabular}

Soil analysis: Soil analysis on nutritional basis (courtesy: Jawaharlal Nehru Krishi Vishwavidyalaya (University), Jabalpur, M.P., India) revealed that fields in this region are deficient in sulphur and contain excess of iron. On an average, sulphur content was reported to be $9.4 \mathrm{ppm}$ as against moderate levels of ca. $30 \mathrm{ppm}$ and iron was 24.9 ppm as against moderate levels of ca. 4.5 ppm (OSU Soil Test Interpretations, www.osuextra.com).

Soil nutrients play a role in root rot as low sulphur and high iron content in soil support fungal growth. Excess of Fe supports germination of fungal spores. The mechanism of biological control of fungal disease by $\mathrm{Fe}$ competition induced by fluorescent pseudomonads is an ecofriendly method of controlling Fusarium root rot and wilt diseases (Simeoni et al., 1987). Sulphur deficiency reduces nodulation and thereafter affects nitrogen fixation (Scherer et al., 2006). Also, it has been reported that elemental sulphur and sulphur containing compounds suppress many fungal pathogens, thereafter, stating its importance in disease control (Cooper and Williams, 2004).

Interview of farmers: In the process of field survey farmers were interviewed and requested to fill survey questionnaire forms. Farmers from four villages of Madhya Pradesh (Patan, Tilgava, Tilhari and Ghana) were interviewed. Farmers of different age groups (20-70 years), varying years of farming experience (2-40 years) and with different socio- economic backgrounds were interviewed. Majority of farmers were poor and illiterate or less educated in this region. The disparities between poor and rich farmers reflected in their method of agriculture and the agricultural produce obtained.

The summary of interview and survey feedback given by farmers is being stated in the following paragraph. A record of video graphic proofs is maintained with the author.

The farmers in these regions mostly sow pea varieties - Arkel, PSM and AP-3. There are other varieties also which are sown in Madhya Pradesh such as E-6, AZAD-P1, AZAD-P3 and Pusa pragati.
Pea sowing season falls in the period of October to February when the temperature ranges from $10^{\circ}$ to $25^{\circ} \mathrm{C}$ through the months including day/night variations. Many farmers here reported of suffering $20 \%$ to $80 \%$ loss in pea production due to wilting and yellowing. Traditional methods of agriculture are used which usually include addition of cow dung manure and periodic irrigation. Some farmers apply NPK fertilizers. Mostly farmers sow the seeds directly without giving any protective pretreatment. In case of using pesticides, they are chemicals such as Bavistin (carbendazim). Biopesticides are less trusted upon. Majority of the farmers were unaware of the ill effects of chemical pesticides due to ignorance and illiteracy and showed a tendency to use them indiscriminately beyond prescribed limits overlooking necessary precautions.

The interview also revealed that farmers were unaware of the schemes and programmes declared by the state and central government for improving agriculture in this region.

Lecture delivered to farmers: Keeping in consideration the feedback obtained from farmers during the survey, a lecture was organized for the benefit of farmers on 12 May 2009 at Government Middle School, village - Khiriya Kala, districtJabalpur, Madhya Pradesh.

The lecture included discussion on general agricultural practices, modern technologies, schemes introduced by the government to promote agriculture and poor farmers.

Schemes, for financially weak farmers, such as $50 \%$ concession in purchase charges of agricultural machines, 30\% concession in purchase charges of seeds, also schemes for irrigation facilities were declared by Madhya Pradesh government (Shrivastava et al., 2007).

Farmers were acquainted with the ill effects of chemical pesticides resulting from their indiscriminate use by showing reports published in a national newspaper (Dainik Bhaskar dated 21 Dec 2008). The newspaper stated death of about one dozen cattle livestock due to excessive use of chemical pesticides in agricultural fields of Shahpura village of Madhya Pradesh (photograph 1). Facts mentioned in the 'Material Safety Data Sheet' for Bavistin - Systemic Fungicide issued by CRPCARE, Australia were also discussed.

At the same time, importance of biopesticides was explained in terms of environment protection, safety 
to human beings and animals. Commercially available biopesticides (http://www.researchandmarkets.com/reports/453021 I) were mentioned, Trichoderma being the most promising of all (Harman, 2006).

The use of chemical pesticides cannot be abruptly stopped but a gradual decrease is necessary. To minimize the ill effects of chemicals, popularization of biological control methods is required. An approach to use chemicals and biological agents in synergism has also been studied ( Mathre et al. , 1995). Other approaches are use of resistant varieties and crop rotation.

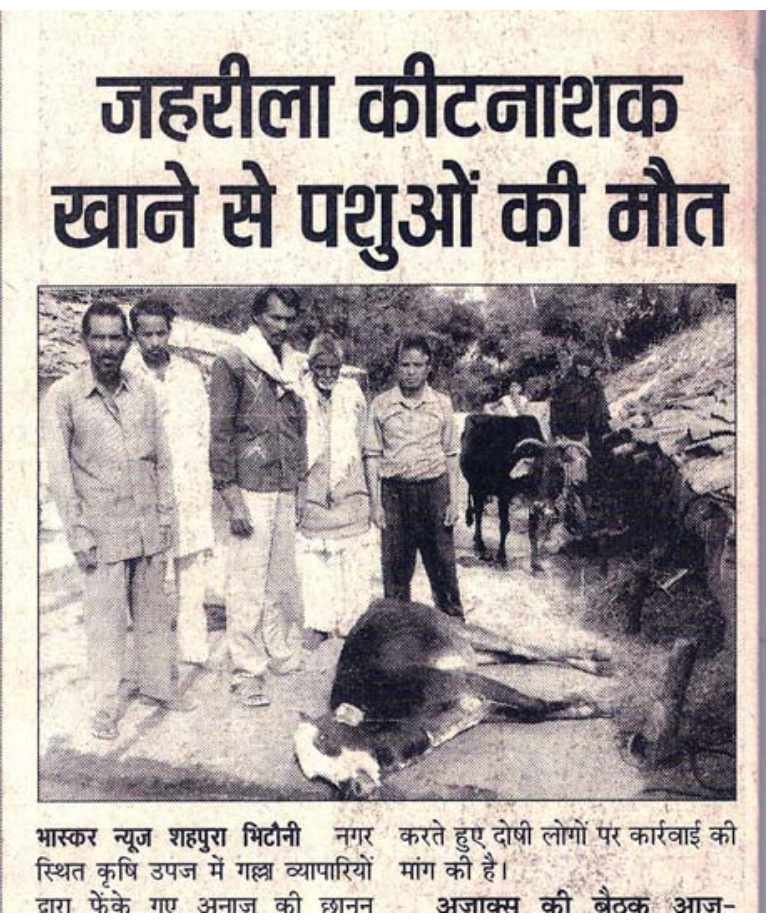

Photograph 1 showing death of cattle livestock due to intake of fodder contaminated excessively with pesticide.

(Courtesy: National newspaper; Dainik Bhaskar dated 21 Dec 2008, India).

Communication with government authorities to convey problems and demands of farmers: The survey report was interpreted. The problems and demands of farmers were listed in the form of a Public Interest Litigation (PIL) dated 12 Aug 2009, attested by Mr. M. P. Kapoor, advocate, High Court of Madhya Pradesh, Jabalpur. The PIL (legal procedures incomplete) was communicated to the Chief Justice, High Court of Madhya Pradesh, Principal seat- Jabalpur, India. Copies of PIL were also communicated to state ministry of agriculture
(Department of Farmer Welfare and Agriculture Development, Vindhyachal Bhawan, Bhopal, Madhya Pradesh ) and central ministry of agriculture (RKVY Cell, Krishi Bhawan, New Delhi).

The main points of litigation include-

- Education to poor and illiterate farmers.

- Farmers to be acquainted with their rights and provisions as mentioned in the legislature.

- Proper and effective training to farmers on modern methods of farming.

- Education to farmers concerning hazards of indiscriminate use of chemical pesticides.

- Efforts to make biological control methods popular by setting up biopesticide and biofertilizer production units and also agricultural information centers in as many villages as possible.

- Effective implementation of schemes and plans declared by the state and central government.

\section{GENERAL CONCLUSION}

As a result of human made monocultures and environmental imbalances which are becoming more obvious each day, new strains of pathogens are reported in different parts of the world every year ( Khaskheli et al., 2008; Garibaldi et al., 2009). Chemical pesticides are widely used throughout the world to control these pathogens. These chemicals mostly prove to be effective and take less time to show results. On the contrary, biopesticides take time to establish themselves in free soil, rhizosphere and rhizoplane and show effect after a complex interaction with the pathogen and the plant (Chakraborty and Chatterjee, 2007).

Yet, excessive use of lethal chemicals in our fields and their consequences are compelling us to find new ways of combating plant diseases. Use of biological control methods, seeds of resistant varieties and crop rotation being some of the methods.

Scientists and research organizations throughout the world have made immense advances in agricultural research. It is necessary to communicate these advances to the farmers in the developing and underdeveloped nations through awareness programmes. Also, correct and effective utilization of funds and resources is required. It has been reported that United Nations has indicated possibility of initiating insurance schemes for crop failure due to climatic disasters such as floods and droughts in Asia, Africa and Latin America ( Murray, 2009). A 
joint effort on a national and international level is important for a fruitful result. Organization of training programmes by developed countries in developing and underdeveloped countries is one such method ( Nelson et al., 2001).

\section{ACKNOWLEDGEMENT}

The author thanks all the farmers of Madhya Pradesh, India and Mr Rajesh Patel, Sharda Biotech agency who have contributed to the survey and sampling procedure. Also, gratitude is extended to Jawaharlal Nehru Krishi Vishwavidyalaya (University), Jabalpur, M.P., India for soil analysis service. The author is also grateful to Mr. M. P. Kapoor, advocate, High Court of Madhya Pradesh for attestation of Public Interest Litigation.

\section{REFERENCES}

Chakraborty, M.R. and Chatterjee, N.C. (2007). Interaction of Trichoderma harzianum with Fusarium solani during its pathogenesis and the associated resistance of the host. Asian J. Exp. Sci. 21(2): 351-355.

Cooper R. M. and Williams J. S. (2004). Elemental sulphur as an induced antifungal substance in plant defense. $\mathrm{J}$. Exp. Bot. 55(404): 1947-1953.

Garibaldi, A., Gilardi, G., Troisi, M. and Gullino, M.L. (2009). First report of fusarium wilt of endive (Cichorium endivia) caused by Fusarium oxysporum in Italy. Plant Dis. 93(10): 1078.

Harman, G. E. (2006). Overview of mechanisms and uses of Trichoderma spp. Phytopathology 96: 190-194.

Hwang. S. F., Howard, R. J., Chang, K. F., Park, B., Lopetinsky, K. and McAndrew, D. W. (1995). Screening of field pea cultivars for resistance to fusarium root rot under field conditions in Alberta. Canadian PI. Dis. Surv. 75(1): 51-56.

Khaskheli, M.I., Pathan, M.A., Jiskani, M.M., Wagan, K.H., Soomro, M.H. and Poussio, G.B. (2008). First record of Fusarium nivale (Fr.) Ces. Associated with mango malformation disease (MMD) in Pakistan. Pak. J. Bot. 40(6): 2641-2644.

Mathre, D. E., Johnston, R. H., Callan, N. W., Mohan, S. K., Martin, J. M. and Miller, J. B. (1995). Combined biological and chemical seed treatments for control of two seedling diseases of sh2 sweet corn. Plant Dis. 79: 1145-1148.

Misra, P. K. (2009). ITCS supported Lifelong learning for Indian farmers: need, challenges and strategies. .J.P. Rohilkhand University, India. http://www.ou.nl/Docs/Campagners/ICDE2009/Papers/ Final_paper_114misra.pdf

Murray, J. (2009). Indian farmers to insure themselves against climate change crop failure. Guardian News and Media Limited. http://www.guardian.co.uk/environment/2009/jun/08/far ming-india

Nelson, R., Orrego, R., Ortiz, O., Tenorio, J., Mundt, C., Fredrix, M. and Vien, N. V. (2001). Working with resource-poor farmers to manage plant diseases. Plant Dis. 85(7): 684-695.

Ondrej, M., Dostalova, R. and Trojan, R. (2008). Evaluation of virulence of Fusarium solani isolates on pea. Plant Protect. Sci. 44(1): 9-18.

Scherer, H. W., Pacyna, S., Manthey, N. and Schulz, M. (2006). Sulphur supply to peas (Pisum sativum L.) influences symbiotic N2 fixation. Plant Soil Environ. 52(2): 72-77.

Shrivastava, M., Mehta, R., Pathak, M. and Kapoor S. (2007). Aagae ayen labh uthayen. Jansampark sanchalanalaya, Bhopal, Madhya Pradesh, India. www.mpinfo.org , www.mpmadhyam.org

Simeoni, L. A., Lindsay, W. L. and Baker, R. (1987). Critical iron level associated with biological control of fusarium wilt. Phytopathology 77: 1057-1061.

Tiwari, S. G., Saxena, k. K., Khare, N. K. and Khan, A. R. (2007). Factors associated with adoption of recommended practices of pea. Indian Res. J. Ext. Edu. 7(2-3): 60-61 